\title{
Kindî Metafiziğinin Temel Kavramları
}

\author{
İrfan GÖRKAŞ*
}

\begin{abstract}
ÖZ
Bu çalışma, öncelikle bir "meta-varlık" çalışmasıdır. Bir meta-varlık çalışması olarak bu yazı, Kindî’nin metafiziğinde yer alan varlık kavramlarına ve varlık felsefesine odaklanmaktadır. Çünkü Kindî ilk İslam filozofudur ve "feylesofu'l-Arab" ünvanıyla tanınmaktadır. Kindî kelam ile felsefe arasında bir köprü isimdir. Felsefeyi teori ve pratik açıdan muhtelif şekilde tanımlar. Kendisinden önce felsefeyle uğraşanlara teşekkür eder. O, İslam düşüncesinde ilk metafizik yazarıdır. İslam felsefe tarihinde ilk felsefe sözlüğünü kaleme alan bir düşünürdür. O, Beytü'l-hikme'de tercüme heyetinde görev yapan bir isimdir. Eseri Aristoteles'in terimiyle İlk Felsefe adını taşımaktadır. İslam düşüncesinde felsefî terminoloji onun metafiziğine dayanmaktadır. Başka bir ifadeyle Türkçe bir metafizik için İslam metafiziği, İslam metafiziği için onun terminolojisi önemlidir. Onun metafiziği İslam metafiziğinin başlangıcıdır. Çünkü o, Arapça felsefe terminolojisinin kontrolörü ve eserlerinde kullanan ismidir.
\end{abstract}

$\mathrm{Bu}$ çalışma, Kindî metafiziğiyle ilgili yapılan ilk çalışma değildir. Böyle bir iddiası da yoktur. Ancak bu çalışma, bir meta-varlık çalışması olarak, Türkçe "varlık” kavramının ötesine odaklanmaktadır. Öte (meta) kavramı, varlığın İslam düşüncesindeki Arapça, Farsça, Türkçe, ...vb. dillerdeki varoluşunu ve formlarını imlemektedir. O nedenle çalışmamız bir ilk örnek olarak Kindî terminolojisine odaklanmaktadır. Bu bakımdan onun terminolojisi İslam düşüncesinin temel ilkesini ve başlangıcını oluşturmaktadır. Kindî felsefesinde meta-varlık, şey, hak, vücûd (insanî varlık ve bilgi), eys, inniyye (varlık), mevcûd (varlık ve cümlede bağ) olmak üzere altı terim olarak varolmakta, Bir

Prof. Dr., Afyon Kocatepe Üniversitesi İslami İlimler Fakültesi, Felsefe ve Din Bilimleri Bölümü, Afyonkarahisar/Türkiye

E-posta: igorkas@aku.edu.tr, ORCID: 0000-0001-7134-225X, DOI: 10.32704/erdem.2021.81.041

Makale Gönderim Tarihi: 13.09.2020 * Makale Kabul Tarihi: 29.11.2021 * (Araştırma Mk.) 
(vâhid) kavramı üzerinden bir-çok felsefesi olarak ortaya çıkmaktadır. Kindî'de Bir sayı değildir. Bir çok değildir. Bir nefs değildir. Sayı ikiyle başlar. İki çokluktur. Bir haktır. Bir el-Hakk’ı ifade ederken birlik, şeylerin (eşyâ) gerçekliği olarak varolmakta, Kindî onları tümeller olarak ifade etmektedir. Böylece varlık varoluşu bakımından birlik ve çokluk olarak ortaya çıkmaktadır. Bu şekliyle Kindî metafiziği, bizim Türkçe "Varlık" kavramımızın “ötesi”ni ve bir örneğini, klasik İslam metafiziğinin de başlangıcını oluşturmaktadır.

Anahtar Kelimeler: Kindi, metafizik, meta-varlık, bir, birlik, çok, tümeller. 


\title{
Basic Concepts Of Metaphysics Of Kindî
}

\begin{abstract}
This paper is a study of "meta-varlık (being)". As a meta-varlık study, it focuses on the concept of varlık (being) in Kindi's metaphysics and his ontology. Because Kindi is the first Islamic philosopher and known as "philosopher of Arab". Kindi provides a logical connection between al-Kalam and Philosophy. He defines philosophy in various ways in terms of theory and practice. He would also like to thank predecessors engaged in philosophy before him. He is the first metaphysical author in Islamic thought and is a thinker who wrote the first dictionary of philosophy in the history of Islamic philosophy. $\mathrm{He}$ is a member of the translation committee of the Bayt al-hikma. His work is entitled by Aristotle as "First Philosophy". Philosophical terminology in Islamic thought is based on his metaphysics. In other words, Islamic metaphysics is crucial for the metaphysics in Turkish and Kindî's terminology is crucial for Islamic metaphysics. His metaphysics is the beginning of Islamic metaphysics. This beginning is an introduction to the metaphysics in Turkish. Because he is the controller of the terminology of philosophy translated into Arabic and uses it in his works.
\end{abstract}

This article is not the first study of the Kindi metaphysics. There is also no such a claim. However, as a meta-varlık (being) study, this article focuses "beyond" the concept of "being (varlik)" in Turkish. Furthermore, meta concept refers to existence and ontology of "being" and forms of it included in Islamic thought in Arabic, Persian, Turkish, etc. languages. Therefore, our study focuses on the Kindî's terminology as a first sample. In this respect, his terminology constitutes the basic principle and beginning of Islamic thought. In the philosophy of Kindî, meta-varlık exists as six terms: thing (şey), right and reality (hak), existence and humanistic knowledge (wujûd), being (ays, anniyya), existent and copula in a sentence (mawjûd) and appears as a one-many philosophy from the principle of One (vâhid) concept. One is not a number in Kindî's thought. One is not many. One is not soul (nafs). The number starts with two. Two is multiple. One is a truth (al-Hakk). While One expresses Reality (el-Hak), Unity exists as the reality of things and Kindî expresses them as universals. Therefore, being has unity and plurality. In this form, the Kindî metaphysics constitutes the "beyond" and an "example" of our Being (Varlık) concept in Turkish and also the beginning of Islamic metaphysics.

Keywords: Kindî, metaphysics, meta-varlık, one, unity, many, universals. 


\section{Giriş}

R çalışma bir "meta-varlık” çalışmasıdır ve kavram İslam metafiziğini
ifade etmektedir. İslam metafiziği teriminde yer alan İslam, özel bir “din, coğrafya ve medeniyet" anlamına gelmektedir. Bu anlamda İslam metafiziği, İslam dininden etkiler alan, başka bir ifadeyle İslam coğrafyasında, İslam medeniyetinde ortaya çıkan her metafiziği ifade etmektedir. Bu anlamıyla İslam, teknik terimde ayırıcı bir fonksiyona sahiptir. $\mathrm{O}$ halde şu soruları sorabiliriz: Acaba az önceki tanımda belirtilen bir metafiziğin varlığından söz edilebilir mi? Eğer söz edilebiliyorsa, o ne tür bir metafiziktir? Onun önü/başı/başlangıc1 nedir? Bu metafiziğin varlığı sürekli midir? Yoksa bir süre var olmuş, sonra varlıktan çekilmiş midir?... Bu tür sorulara cevap verebilmek için öncelikle, onun başlangıcını tespit etmek, gerekmektedir. Metafizik kavramı ise Kindî felsefesinde yer alan varlık kavramlarını ve onun felsefe ve metafizik anlayışını ifade etmektedir.

\section{Kindî’de Felsefe}

İslam düşüncesinde Kindî’yi öne çıaran yönlerinden birisi, hiç şüphesiz onun ilk İslam filozofu olmasıdır. İkinci olarak onun felsefeye dair yaptığ 1 muhtelif tanımlarıdır. Kindî İlk Felsefe'de felsefeyi tanımladığı gibi, Fi'lHudûd' da da bu tanımları tekrarlamış, felsefe tanımına verdiği önemi göstermiştir. Çünkü onun tanımları, felsefenin konusunu, amacını veren ve felsefî etkinliği belirleyen tanımlardır. Biz onun tanımlarını üç gruba ayırabiliriz.

El-Hudûd'taki ilk tanımı, felsefenin adından hareketle yaptığı felsefeye ve ilk felsefenin bir araç ve sanat olduğuna dair yaptığı tanımdır. Buna göre felsefe, hikmet sevgisidir, filozof hikmet seven anlamina fila ve sufa'dan birleşik bir kavramdır (Kindî 2014a: 184). El-Cevâhir el-Hamse'de felsefeyi genel anlamıla teorik ve pratik olarak ikiye ayırır, Kitâbu'l-Makûlât'ta onları akıl ve duyu bilgisi olarak açıkladığını belirtir. Aklî olan, ilahî varlıkların (eleşyâ el-ilâhiyye) ve sonradan olan varlıkların bilgisidir. O nedenle özünde felsefe, zihnin (nefs) disipline edilmesidir (Kindî 2014b: 286). İlk Felsefe'de ise felsefe, bir sanattır ama insan sanatlarının değer ve mertebe bakımından en üstünüdür (Kindî 2014c: 126). Bilindiği gibi "İlk Felsefe" ismi, metafizik çalışmalara verilen dört isimden birisidir. Diğer üçü ise Harfler Kitabı, Teoloji (el-îlâhiyât) ve Metafizik (Mâbadettabîa) isimleridir. Kindî’ye göre ilk felsefe felsefenin en değerlisidir, çünkü o, her gerçeğin sebebi olan "İlk Gerçek (el-hakk el-evvel)"in bilgisini veren bir sanat olmaktadır. 
Kindî’nin ikinci grup tanımı pratik açıdan yaptığı tanımlardır. Onlardan birisine göre felsefe, insanın gücü yettiği ölçüde fiillerini yüce Allah'ın fiillerine benzetmesi çabasıdır. Bu tanım, felsefenin pratik açıdan tanımlanmasıdır. $\mathrm{Bu}$ anlamda felsefe ahlak ve siyaseti içermekte, insanın kemâlini ve mutluluğunu amaçlamaktadır. İkinci tanımı, yine pratik (fiil) açıdan yapılan bir tanımdır. Buna göre felsefe ölümü amaçlamaktır (inayet), yani tercih etmektir. Bu tanımı yapanlar, iki tür ölümden bahsetmektedirler. Birincisi doğal ölüm (mevt tabiî), ikincisi felsefî ölüm yahut iradeli-kasitlı ölüm. Birincisi nefsin bedeni terk etmesiyle gerçekleşen ölümdür. İkincisi insanın iradeli-kasıtlı olarak arzuları terk etmekle gerçekleşen ölümüdür (imâtetü'ş-şehevât). Kindî’ye göre erdemlere giden yol, arzuların ölümünden geçmektedir. O nedenle kadîm filozoflar hazların kötü olduğunu, onlardan uzak durulması gerektiğini belirtmişlerdir ki bu hal ahlaktır.

Kindî’nin üçüncü grup tanımı, teorik açıdan yaptığı tanımlardır. İlk tanımına göre felsefe, insanın kendisini (nefs) bilmesidir. Bu tanımda bilinmesi belirlenen felsefe alanı, insanın kendisidir. Kindî’ye göre insanın özü yani nefsi cevherdir, insan kendisini tanıyınca cismi de arazlarıyla bilmiş olur. Çünkü insan küçük âlemdir. Kindî’nin teorik açıdan yaptığı bir diğer tanımı şudur: Felsefe, insanın gücü ölçüsünde "ebedî ve küllî varlıkların (el-eşya el-ebediyye el-külliyye)" hakikatini, mahiyetini ve sebeplerini bilmesidir (Kindî 2014a: 185; Kindî 2014c: 126).

\section{Felsefenin Konusu}

Kindî’nin birinci grup tanımında yer alan felsefe üzerinde durulmayacaktır. Kindî’nin ikinci felsefe tanımında verdiği "ebedî ve küllî şeyler" terimi, metafizik açıdan felsefenin konusunu veren terimdir. Terime ve tanıma göre felsefe, "ebedî küllî şeyler"in hakikatini, mahiyetini ve sebeplerini konu edinmektedir. O halde Kindî’ye şu soruları sormalıyız. Acaba "ebedî küllî şeyler" terimi, ne anlama gelmektedir? Şey'in kendisi nedir? Kindî’nin "ebedî ve küllı̂” kavramlarıyla ayırıp özelleştirdiği "şeyler (el-eşyâ)" dışında, bir başka şeyler var mıdır? Varsa bunlar neler olabilir? Onların bir mahiyeti var mıdır, onların varlık sebepleri nelerdir?... Kindî’nin belirlediği “şeyler" konusundaki bu sorular bizi, Kindî’nin iki tür şey kabul ettiği sonucuna götürmektedir. Birisi tanımda belirtilen ebedî ve küllî şeyler, diğeri ebedî ve küllî olmayan şeyler. O halde şimdi biz Kindî’nin metafiziğine daha yakından bakabiliriz. 


\section{Kindî’de Metafiziğin Mahiyeti: Şeyin Hakikati Bilgisinin İçeriği}

Kindî Illk Felsefe'nin girişinde, felsefenin “var mıdır (hel)? Nedir (mâ)? Hangisidir (eyyü)? Niçin (lime)?” temel sorularını ve fonksiyonlarını verdikten, geçmişte felsefe çalışması yapanlara teşekkür ettikten sonra, felsefe-din ilişkisine yer vererek İslam metafiziğinin konusunu, bu sefer "şeyin hakikatini bilmek (ilmü'l-eşyâ bi-hakâikiha)" olarak belirler ve hakikatler bilgisinin içeriğini verir.

“Çünkü Şeyin Hakikatleri Bilgisi (ilmü’l-eşyâ bi-hakâikiha) içerisinde, ilahîliğin bilgisi (ilmü'r-rububiyye), birliğin bilgisi (ilmü'l-vahdâniyye), erdemin bilgisi (ilmü'l-fazîle), tüm yararlı olanın bilgisi (ilm-i külli nâf'), yararlıyı elde etmenin yolu/yöntemi bilgisi, tüm zararlı olandan sakınma ve korunmanın bilgisi vardır (Kindî 2014c: 129; İbn Hazm 2015: 18, 19).”

Kindî’nin belirlediği bu "Şeyin hakikati bilgisi” kavramı ve içeriğine, ilk İslam filozofu olması bakımından Kindî’nin ve İslam metafiziğinin başlangıcıdır diyebiliriz. Çünkü kavram genelde iki tür bilgiyi içermektedir. Birincisi şeylerin bilgisini, ikincisi şeylerin hakikatleri bilgisini. Birincisi Fiziğin, ikincisi Metafiziğin bilgisidir. Kindî ikinci bilgiyi, Rubûbiyyet ilmi, Vahdâniyet ilmi, Fazîlet ilmi ve Yararlının İlmi olmak üzere dört kavramla açıklamaktadır. O halde İslam metafiziğinin başlangıç kavramı ve sorunu, şeyin hakikati ve ne olduğu sorunudur. Bu sorun illet kavramıla birlikte ifade edildiğinde, şeyin hakikati doğrudan bir nedensellik sorunu olarak karşımıza çıkmış olmaktadır. Rubûbiyyet ilmi, Vahdâniyet ilmi, Fazîlet ilmi ve Yararlının İlmi ve yöntemi söz konusu olduğunda Kindî’nin ifadesinde, İslam metafiziğinin ikinci başlangıç ilkesi, "peygamberler" olarak belirlenmiş görünmektedir. Onlar şeylerin hakikatine dair Allah’tan bilgiler getirmişlerdir (Kindî 2014c: 129). Kindî’nin, Peygamberleri İslam metafizik tarihinin ilk örnekleri olarak kabul etmesi ise nübüvvetin metafiziğin konusuna eklenmesi meselesini gündeme getirmektedir.

\section{Kindî Metafiziğinde Varlık Kavramları}

Kindî, metafiziğinde varlıkla ilgili farklı kavramlar kullanmaktadır. Bunlar, şey, vücûd, inniyye, eys, mevcûd ve hakk kavramlarıdır.

\section{Şey Kavramı}

Günümüze ulaşan eserleri içerisinde Kindî, özellikle İlk Felsefe'de ve elHudûd'da, şey kavramına ayrı bir bölüm açmaz, müstakil olarak şey kavra- 
mını ele almaz. Bilindiği gibi şey, dilemek, istemek anlamına gelen isim-mastar bir kavramdır. Kavram, bilinebilen, hakkında haber/bilgi verilebilen diye tanımlanabilir. Diyanet Ansiklopedisi'ne göre kavram, menşei bakımından Kur'an'a dayanmakta ve İslam düşüncesinde önemli tartışmalar başlatmaktadır. Sözgelimi şey kelimesi, yalnızca fiilen var olan bir nesneye mi yoksa henüz mevcut olmamakla birlikte var olması mümkün olan bir nesneye mi karşıllk gelmektedir? Bu bağlamda başka bir soru, Allah'a şey denilebilir mi? Bir diğer sorun, Allah'ın bir şeyi yaratmayı irade ettiğinde ona yalnızca "ol" der âyetinde (Yâsîn 36/82) geçen şey kavramıla ilgilidir. Ayette Allah "yok olan bir şeye", "ol" diye hitap etmektedir. Hitap edilen "şey" yokluk olduğuna göre yokluk bir şey midir değil midir? Bu ve benzeri sorular, önce teolojik boyutta başlamış, sonra ontolojik boyut kazanarak gelmiş sorulardır (Kutluer 2010: 34-36).

Kindî’nin şey’le ilgili kullandığı “ebedî ve küllî şeyler (el-eşyâ el-ebediyye el-külliyye)" kavramına ilaveten "şeylerin hakikati (el-eşyâ bi-hakâikiha)" kavramına tekrar işaret etmek istiyoruz. Kavramlar, filozofun ulaşmak istediği amacı vermektedir. Amaç "şeylerin hakikati”ni bilmek ve eylemde bulunmaktır. Özetle, felsefe şeyleri değil, şeylerin gerçekliğini (hakikati) bilmek ve gerçekliğe göre eylemini düzenlemektir. Bir değerlendirmeye göre hak kavramı, Kindî metafiziğinin üzerine bina edildiği üç temel kavramdan birisidir (Türker 2018: 53-66).

Kindî’nin şeyler (el-eşyâ) ve hakikatleri (hakâikuha) ayırımı, onun iki varlık dünyasını imleyen bir ayırımıdır. Bu ayırımı, varlı̆ğ ifade etmek üzere kullandığı aşağıda ele alınan diğer kavramlarda da görülmektedir. Sözgelimi Kindî, eserinin girişinde illet/sebep/ten söz ederken kullandığı "her şeyin varlığının ve sürekliliğinin illeti, Gerçek’tir (و علة وجود كل شئ وثباته الحق "و)" ifadesinde varl1k için "şey" ve "vücûd", varlı̆̆ın sebebi (illet) için gerçek diye çevirdiğimiz "el-Hak" kavramlarını kullanmaktadır. İllet anlamında bu gerçek, Tanrı'dır. Anlaşılacağı gibi burada vücûd kavramı, şey’e ait bir kavramdır. Yine Kindî, “varlığ1 olan her şeyin bir gerçekliği vardır (لأن كل ما له إنبّّة له حقيقة)" ifadesinde şeyin varlığı için "inniyye" kavramını; "Hakkın ilk fiili, varlıkları yokluktan tesis etmektir (انّ الفعل الحقّيّ الأول تأسيس الأيُسات عن ليس) ifadesinde yokluktan (leys) tesis edilen varlık için "eys" kavramını; "şu halde Gerçek yani Hakk, zorunlu olarak vardır (فالحق اضطر ار أ موجود)" ifadesinde "vardır" yüklemi için "mevcûd" kavramın1; "o nedenle varlıklar vardırlar (اذفرًا لانّّات موجودة)" ifadesinde hem inniyye'nin çoğulu "inniyyât"1, hem "mevcûd”"u yani "varlıklar vardır"1 birlikte kullanmaktadır (Kindî 2014c:126). Bu kullanımlarda, vücûd her nesneyi 
(şey), inniyyet varolan her gerçekliği (küllü mâ lehu), eys yokluktan ortaya çıkmış gerçekliği yani bilfiil varlığı, mevcûd sözel ve dilsel ifadedeki varlığ1 yani “vardır" fiilini/yüklemini ifade etmek için kullanılmaktadır. Hak veya hakikat ise ya şeylerden hareketle ulaşılan bir varlık veya ulaşılmak istenen amaç varlık, teknik terimle "illet” olarak görünmektedir. Böylece Kindî, inniyye veya inniyyât kavramı ile vücûd ve eys kavramlarını aynı anlama gelecek şekilde gerçek/reel varlık karşılığında, hakk'1 illet, mevcûd'u yüklem için dilsel bağlamda kullanmaktadır.

\section{Vücûd Kavramı}

Kindî’nin vücûd kavramını, yukarıda genel gerçeklik anlamında kullandığını söylemiştik. İlk Felsefe'nin ikinci bölümünün (fen) ilk kısmında (cüz) ise Kindî, vücûd kavramını, daha farklı bir anlamda ve insan için kullanır, varlığı insana sıfat yaparak yeni bir varlık alanını ifade eder. Bu varlık, "insanî varlık"tır ve insan varlığı iki kısımdan, Kindî’nin deyimiyle “iki varlık (vücûdân)"tan teşekkül etmektedir. Başka bir ifadeyle Kindî insanî varlığ1 ikiye ayırır (ان الوجود الانساني وجودان...) (Kindî 2014c: 131).

İki insanî varlıktan biri, tabiata daha uzak, insana daha yakın olan varlıktır ki bu tür varlık, duyuların varlığıdır (vücûdu'l-havâs). Bunlar, insanın ortaya çıtığ 1 andan itibaren sahip olduğu, insan cinsinin tümünün ve insan cinsinin dışındaki çoğu canlıların, yani hayvanların, sahip olduğu varlıktır (Kindî 2014c: 131). Kindî’ye göre duyu varlığı (vücûd bi'l-havâs), duyunun (el-his) zamansız ve zorluksuz duyumlaması sırasında ortaya çıkar. Çünkü nesnelerin hareket türlerinden birinin etkisiyle duyu varlığ değişikliğe uğrar. $\mathrm{Bu}$ değişikliğe bağlı olarak nicelik ve nitelik durumları ortaya çıkar. Bunlar, azlık, çokluk, eşitlik, eşitsizlik, gibi nicelik değişimleriyle ilgili; benzerlik, benzemezlik, güçlülük, zayıflık, gibi nitelik değişimleriyle ilgili durumlardır. O halde zaman, sürekli bir zeval ve kesiksiz bir değişim içindedir. Duyu varlığı, insanın tasarım/kavrama (el-musavvira) gücünde ortaya çıkar, tasarım gücü duyu varlığını hafizaya iletir. Böylece duyu varlığı, canlının zihninde (nefsi'l-hayy) bir idea (mütemessel) ve kavram (mütesavver) olarak yer alır, ama duyu varlığı hafızadayken duyularla ilişkilidir.

İnsanî varlığın ikincisi, insana daha uzak, fiziğe daha yakın olan varl1ktır. Bu varlık, akıl varlığıdır (وجود العقل). Özetle Kindî ikiye ayırdığ insanî varlığ1 duyu (hissî) varlığ1 ve akıl (aklî) varlığ1 olarak belirler. "Gerçekten insanî varlık iki varlık olmuştur. Hissî varlık ve aklî varlık (بحقّ ما كان الوجود وجودين. وجود الحسي و وجود العقلي)." Ancak her iki varlığın 
kaynağını 'şey (el-eşyâ)' kavramı oluşturmaktadır ve Kindî burada insanî varlık için sadece "vücûd"u kullanmakta, eysât ve inniyyât kavramların1 tercih etmemektedir. Vücûd'un bu tür kullanımı önceki kullanımına göre daha özel bir kullanımdır. Bu özel yani insana has kullanım, daha sonra Yunus Emre, Âşık Paşa, Kaygusuz gibi Yesevî geleneğine mensup Selçuklu ve Osmanlı dönemi şair-düşünürlerin Türkçe şiirlerinde devam edecektir.

Kindî’ye göre aklî varlık hissî varlıktan, hissî varlık şeylerden (eşyâ) elde edilmektedir. Kindî’ye göre şeyler bu anlamda, tümel (küllî) ve tikeldirler (cüzî). Aristocu bir anlayışla Kindî, tümeli (küllî) türlerin nispet edildiği cinsler, şahısların nispet edildiği türler olarak; tikeli (cüzî), türlere nispet edilen şahıslar olarak belirtir. Böylece Kindî, cinsler, türler ve şahıslar olmak üzere üç tür varlığa ulaşır. Tikeller maddeye bağımlıdır ve duyuların alanına giren varlıkları, cinsler ve türler ise aklın alanına giren varlıkları oluşturur. Bu bakımdan sonunculara Kindî, "insanî akıl (el-aklü’l-insânî)” adını da vermektedir. Kindî, duyu varlığını zihindeki bir imaj (mesel, mütemessil), akıl varlığını aksiyomlar (el-evâil el-akliyye) olarak belirtir. "Alemin haricinde ne doluluk ne boşluk ne de cisim vardır" önermesi, onun aklî varlığa verdiği örneklerden birisidir. Zira doluluk, boşluk kavramlarının duyuyla herhangi bir ilgisi bulunmamaktadır. "Sonlu olan bir şey sonsuz olamaz" verdiği bir başka aksiyomdur. Özetle, Kindî’nin, vücûd kavramını, insana ait olan kavram ve aksiyomlar için kullandığını söyleyebiliriz.

\section{Eys Kavramı}

Kindî’nin kullandığı varlık kavramlarından birisi "eys" kavramıdır, demiştik. Bu kavramı İslam düşüncesinde kullanan ilk kişi, Kindî’ dir. Kavrama İlk Felsefe ile Gerçek ve Mecazi Fail Üzerine'de yer vermiştir (Kindî 2014c: 144-15; Kindî 2014d: 190). Eys, Kindî’nin yokluk (leys) kavramının karşıtı olarak kullandığı bir kavramdır. Kavram daha sonra Osmanlı düşüncesinde de yer alacaktır (Öçal 2000: 143; Erdem 2012: 87-116). O nedenle eys, Arap dilinde çok az bir kullanım alanı bulunan ve ilk defa filozof Kindî’nin felsefî risâlelerinde görülen terimdir. Bir çalışmaya göre Eys terimini Kindî, Allah'ın varlığı, sıfatları ve âlemin yaratılmışlı̆̆ını söz konusu ederken kullanmıştır. Harizmî’nin söylediklerine bakılırsa kavram, İslâm kelamcılarının eserlerinde de kullanılmaya bir süre devam etmiştir. Ancak kavram bütün kelamcılarda değil bazı İsmailî kelamcıların eserlerinde sadece diğer varlıklar için kullandıkları görülmüştür (Yavuz 1995: 1). 
Kindî "bir şeyin varlık sebebi” meselesini analiz ederken Illk Felsefe' nin üçüncü kısmının (fen) ilk cüzünde, eys kavramını kullanmaktadır. Kindî’ye göre bir şeyin, kendi varlığının sebebi olması mümkün değildir. "Bir şeyin kendisi (zâtuhu)" deyimiyle Kindî, ilkçağ felsefesinin varlık tartışmalarında yer alan dört ihtimalden söz eder. Onlardan birincisi, varlık (kâin) vardır (eys), zâtı yoktur (leys). İkincisi varlık (kâin) yoktur (leys), zâtı vardır (eys). Üçüncüsü varlık (kâin) yoktur (leys), zâtı yoktur (leys). Dördüncüsü varlık vardır (eys), zâtı da vardır (eys) ihtimalleridir. Kindî sırasıyla üçüncü ihtimali, ikinci ihtimali, birinci ihtimali ve dördüncü ihtimali ele alır. Onların mümkün olmad1ğını belirtir. Sonuç olarak bir şeyin kendi varlığı (zâtı) için sebep olmasının imkânsız olduğu sonucuna ulaşır (Kindî 2014c: 144, 145). Gerçek ve Mecazi Fail Üzerine'de fiili ele alan Kindî, "Hakk'ın ilk fiili”ni -yukarıda da verildiği gibi- “varlıkların yokluktan tesisi (انّ الفعل الحقّيّ الأول تأسيس الأيُّات عن ليس)" olarak ifade eder. Bu tesis yaratmadır, her sebebin gayesi olan yüce Allah'a özgü olan fiildir. Çünkü Kindî’ye göre varlıkları (eysât) yoktan tesis/var etmek O'ndan başkasına ait değildir. Kindî bu fiile örneksiz varetme (el-ibdâ') adını vermektedir (Kindî 2014d: 190).

Kindî’nin eys'i ikinci tür kullanımı, onu "vardır (mevcûd)" yerine kullanmasıdır. $\mathrm{Bu}$ tür kullanımı Kindî "o odur, o o değildir" şeklindeki ifadesinde kullanmıştır. Bu kullanıma Kindî’nin çokluğu bir zıtlık olarak değerlendirirken kulland1ğ1 "o halde o (zitlık) hem varlıktır/vardır hem yokluktur/yoktur (فهي أيس ليس)" ifadesini örnek olarak verebiliriz. Kindî ifadesinde, mevcûd'un yerine "eys" ve "leys"i kullanmayı tercih etmiş, "Zitlık eys'tir" ifadesinde Kindî, "eys"i "vardır (mevcûd)" yüklem/fiil anlamında kullanmıştır (Kindî 2014: 155).

Netice itibariyle Kindî, eys'i üç şekilde kullanmış olmaktadır. Birincisinde gerçeklik, reel nesneler (eşyâ) için kullanmıştı. İkincisinde yokluktan örneksiz oluşturulmuş bilfiil varlıklar için kullanmakta, üçüncüsü "olmak (kâne)" fiilinin haberi olarak "vardır (mevcûd)" fiilini ifade etmek üzere 'var'ın yerine kullanmaktadır.

\section{Mevcûd Kavramı}

Kindî’nin mevcûd kavramını, Illk Felsefe 'nin girişinde “vardır” yüklem-fiil olarak kullandığını söylemiştik. Yine Illk Felsefe 'nin üçüncü kısmının ilk cüzünde Kindî, varlığın birlik ve çokluk (vahdet-kesret) ilişkisini ele alırken "mevcûd"a yer vermektedir. Sözgelimi Kindî’ye göre çokluksuz birliğin olması mümkün değildir. Çokluk olmadan birlikten söz etmek, eşyada zıtlığın (muzâdda) olmadığını iddia etmek anlamına gelecektir. Oysa zıddın başkası, yine bir zıttır. 
Burada sözü edilen "başkalık” Kindî”ye göre en az iki şeyde gerçekleşmektedir. İki şey ise bir çokluktur. Buna göre çokluk yoksa zıtlık yoktur. Zıtlık varsa zıtlık, yani çokluk vardır. Kindî burada bir çıkarım yapar ve "mevcûd"u kullanır. "Zitlık vardır. O halde çokluk vardır (و المضادة موجودة فالكثرة موجودة)." Kindî analizinin başında "çokluğun var olmadığını (leyset mevcûde)" farzetmişti. Analizin başlangıç ve sonucu birlikte düşünüldügünde bu analizin sonucu, "zıtlık vardır, zıtlık yoktur" anlamına gelecek, bu sonuç imkânsız bir çelişkiyi ifade edecektir. O halde çokluğun olmaması mümkün değildir. Burada Kindî, "o halde o (zitl1k) hem varlıktır hem yokluktur (فهي أبس ليس)" ifadesinde görüldügü gibi mevcûd'un yerine hem "eys"i hem "leys"i kullanmayı tercih etmiş, "eys"i "vardır (mevcûd)" yüklemi anlamında kullanmıştır. Bu kullanımın anlamı Kindî metafiziğinde eys'in, "mevcûd"dan daha genel kullanımı olduğudur.

Kindî mevcûd kavramını, birlik-istisna ilişkisini ele alırken yine "vardır" yerine kullanır. Yani birlik varsa, istisnanın olmaması gerekir. İstisna ise bir ve birden çok şeyleri diğerlerinden ayırmaktır. Bunun anlamı, istisna varsa çokluk vardır (mevcûde) demek olur. O halde istisna ve istisna edilenin her ikisi de var olduğuna (mevcûdân) göre çokluk vardır. Oysa başlangıçta istisna var sayılmamıştı. Gelinen nokta ise "istisna vardır, istisna yoktur" gibi bir çelişkiyi içermektedir. Sonuçta Kindî’ye göre çokluğun olmaması imkânsızdır. Yani çokluk vardır.

Kindî, benzer şekilde birlik-farklılık (tebâyün) ilişkisini, farklılığın olmaması varsayımından hareketle ele alır. Önce çokluğun varlığına (mevcûde), sonra farklılığın varlığına (mevcûde) ulaşır. Birlik-ittifak, ihtilaf, ittisal ve iftirak ilişkisini ele alır, yukarıdaki yöntemle önce olmadıklarını varsayar. Sonra onların varlıklarından çokluğun varlığına, çokluğun varlığından ittifak ve ihtilafin varlığına, ittifak ve ihtilafın varlığından çokluğun (kesret) varlığına ulaşır. Benzer yöntemle çokluğun varlığını, başlangıç, orta ve son, parça, parçaların sahibi/bütün, şekil, sükûn, hareket kavramlarıyla ele almayı sürdürür. Bu kavramlardan çokluğun varlığına ulaşır. Aksi durumda, yani çokluksuz birliğin olması durumunda, sözü edilen niteliklerin varlıkta olmamasi gerekecektir.

"Bütün anlattıklarımızdan, çokluksuz birliğin olamayacağı ortaya çıkmıştır. Yukarıda geçtiği üzere eğer öyle olsaydı parça ve bütün olmazdı. Bütün bu araştırmalardan, bahsettiğimiz şeylerin hiçbirisinde birliksiz çokluğun olmadığı, bazı araştırmalardan ise çokluksuz birliğin asla bulunmadığı açığa çıkmış, "varlığın yapısının (tıbâu'l-eşyâ)" birlik-çokluk (vahdet-kesret) olduğu anlaşılmıştır. (Kindî 2014c: 157, 158)" 
Kindî’nin varlığın yapısının "birlik-çokluk (vahdet-kesret)" olduğunu söylemesi, onun varlık dünyasını ikiye ayırdığının bir diğer göstergesidir. Birincisi çokluk olarak ifade ettiği şeyler dünyası, ikincisi birlik olarak ifade ettiği vücûd dünyasıdır. Şeyler, fiziğin şahıslar dünyasıdır. Kindî bu dünyayı aşağıda 'tikeller (el-eşyâ el-cüz'iyye)' kavramıyla ifade edecektir. Vücûd ise insanın kavramlar ve aksiyomlar dünyasıdır. Kindî bu dünyayı "küllîler" kavramıla ifade edecektir. Şimdi Kindî’nin söz konusu insanî varlık, diğer adıyla küllîler dünyasına yakından bakabiliriz.

\section{Kindî’de Lafız ve Tümeller}

Kindî küllîler ve cüzîler dünyasını, "çoklukta birlik" meselesi temelinde, "lafız"dan hareketle ele alır. Bilindiği gibi lafız, sözlükte atmak, firlatmak, ölmek, konuşmak ve söz söylemek anlamlarına gelmekte, ağızdan çıkan söze 'lafız' denilmektedir (İbn Manzur Trhsz: 4053). ${ }^{1}$ Kindî’ye göre sanatların sanatı olan felsefenin işi, lafızla uğraşmaktır, ama felsefe, her lafızla uğraşmaz. O nedenle Kindî, lafzı, anlamlı (zî mana) lafiz, anlamsız (gayrı zî mana) lafız olmak üzere ikiye ayırır. Felsefe bu iki tür lafızdan ancak birincisine dayanır, yani felsefe anlamsız lafizlarla uğraşmaz (Kindî 2014c: 145). Çünkü bu tür lafizların varlıkla bir ilgisi yoktur.

Kindî anlamlı lafzı da kendi içinde ikiye ayırır. Biri küllî (tümel) ve diğeri cüzî (tikel) lafız. Kindî’ye göre felsefe, tikeller (el-eşya el-cüz’iyye) üzerinde durmaz. Çünkü Kindî’ye göre tikeller sonsuzdur ve sonsuz olanın bilgisini kuşatmak ise mümkün değildir. Bu bakımdan felsefe, yukarıda belirtildiği gibi şeylerle değil, onların hakikatiyle meşgul olur. O nedenle felsefe, ancak hakikatin bilgisini kuşatan tümel/küllî kavramları konu edinir. Bu kavramlar sinırlıdır (el-mütenâhiye). Kindî’nin tümellerle ilgili el-Hudûd'taki bu tanımı, anlaşılacağı gibi ünlü eseri İlk Felsefe'nin girişinde yaptığı felsefe tanımının bir tekrarı durumundadır. İlk Felsefe'nin girişinde yaptı̆̆ tanıma göre felsefe, insanın gücü ölçüsünde elde ettiği şeylerin hakikatinin bilgisi, sonlutümel varlıkların (eşyâ) bilgisidir. Başka bir ifadeyle bu tümeller, bir yönden birer lafızdırlar ve sonsuz/sayısız varlığa (eşyâ), yani tikellere ait hakikatlerdir; diğer yönden tümel olmaları bakımından Kindî’nin “sonlu varlıkları'dır (el-eşya el-mütenahiye)". Bu bakımdan tümeller, Kindî’nin iki dünyasının ortak bağını oluşturmaktadırlar diyebiliriz. Kindî düşüncesinde bu ortak bağ1 kuranlar, şahısların türleri ile türlerin cinsleridir (Cihamî 2002: 18). Kindî’ye göre tümellere (cins ve tür) ait bir başka husus, onların müşterek/ortak birer

İbn Manzur, Lisanu'l-Arab, Daru'l-mearif, Trhsz. Kahire, c.5, s.4053. 
kavram olmalarıdır ve onlar çok şey arasında ortak kullanılmaya müsait kavramlardır. Tümellerdeki bu ortaklık, "lafızda ortaklık" ve "anlamda ortaklık" olmak üzere ikiye ayrılır. Ayn kavramının, göz (ayn), pınar (ayn), hançer (ayn) anlamlarını içeren ortaklığı lafzî ortaklık; varlık kavramının kadîm ve hâdis bütün varlıklardaki ortaklığı anlam ortaklığıdır, diğer adıyla bu ikinci tür ortaklık manevi ortaklık olmaktadır (Amidî 2016: 59, 60). ${ }^{2}$

\section{Özsel (zâtî) Tümeller: Cins, Tür ve Fasl}

Kindî, tümel varlıkları (el-eşya el-külliyye) genel olarak ikiye ayırmaktadır. Tümeller ya özsel (zâtî) olurlar, ya özsel (zâtî) olmazlar. Özsel yani zâtî olan, şeyin özünü var kılandır (mukavvim). Bu mukavvim, onun varlı̆̆ıdır (vücûd). Onun varlığı, onun şey olmasını ve sabit olmasını sağlamaktadır (kıvam). Böylece Kindî varlık ile iki hususu belirtmiş olmaktadır. Birincisi şey'in sübut bulmasını, yani kuvveden fiile çıkıp var (şey) olmasını, ikincisi şeyi var kılan mukavvimi, yani şey’in özsel ilkesini. Bu iki hususa (şey ve ilkesine), Kindî hay (canlı) ve hayat (canlılık) kavramlarını örnek olarak verir. Yani canlı'nın (hay) varlaşması (Kindî'nin deyimiyle kıvamı ve sübutu), hayat iledir. Canlılığın (hayat) yokluğu, canlının bozulması ve onun dağılmasıdır, yani canlı varlığın varlık alanından çekilmesi demektir. Canlılık (hayat), canlının (hay) özsel ilkesidir. Bu ilke, "cevherî” ilkedir. Yani canlılık (hayat) canlıların cevhersel varlık ilkesidir (kıvam). Kindî, Risale fi'l-hudûd ve'r-rüsûm'da cevheri, "kendi kendine yeterli olan" diye tanımlamaktadır. Cevhersellik varlıkta "kendi kendine yeterlilik" öz-niteliğini ifade etmektedir. Bu öz-yeterliğine ilaveten cevherin bir diğer niteliği, arazların taşıyıcısı olmasıdır. Bu bakımdan o değişmezdir, ama nitelenendir ve artışı kabul etmez. Onun için, oluş ve bozuluş söz konusu olmaz. Çünkü artış, cevherde değil, cevhere arız olanlardadır (Kindî 2014a: 179).

Kindî cevheri de ikiye ayırır. Cevher ya toplayıcı ve bir araya getiricidir (câmi') ya da ayırıcıdır (müferrik). Toplayıcı ve bir araya getirici cevher, birçok şey'de/nesne'de gerçekleşir. İlaveten cevher, şeylerin her birine tanımını ve onlara kendi ismini vermektedir. Böylece cevher, şeyleri aynı isim ve tanım altında toplamakta ve onları bir araya getirmektedir. Neticede cevher birçok şeyi bir arada ifade eder. Mesela insan terimi gibi. İnsan terimi, tek tek her insan için isim olarak kullanılır, çünkü insan lafzı bu kullanımda şahıslarda, yani her bir insanda gerçekleşir. Onların her birinin adı insan olduğu gibi

Seyfüddin Ali b.Muhammed el-Âmidî, El-Mübin fi şerhi meânî elfâzi'l-hukemai ve 'l-mütekellimin, çev.B.Taşkın-O.N.Demir, İz Yayıncılık, İstanbul 2016, s.59, 60. 
onlar bu isimle insan lafzına mensup (insanî) olurlar. İnsanların mensubu olduğu bu insan lafzına, tür (suret) denilir (Kindî 2014c: 146).

Kindî tür için iki kavram kullanmaktadır. Birincisi burada verdiğimiz, 'suret' kavramıdır. İkincisi mantığın 'nev' kavramıdır. Kindî “suret”i el-Hudûd'da, "bir şeyi o şey yapan" lafız diye tanımlar (Kindî 2014a: 179). Kindî”ye göre bir tür (suret), ya bu şahısların her birisinde gerçekleşir ya da birçok türde gerçekleşir. Sözgelimi canlı (hay) lafzı, ikinci anlamda, yani canlı türlerin her bir türünde gerçekleşir. İnsan, at türleri gibi. Bu çeşit lafza, "cins" adı verilir. Böylece Kindî, lafżın anlamının şahıslarda gerçekleşmesini "tür (suret)", türlerde gerçekleşmesini "cins" olarak belirlemiş olur. Bu bağlamda Kindî, cins ve tür kavramlarını toplayıcı ve bir araya getirici cevher olarak, birincisinin türlerde, ikincisinin şahıslarda gerçekleşen lafız olarak vaz etmiş olur ki bu ikincisi "varlık (şey)" olarak ifade edilen lafızdır. Tümel varlık ise form kazanmış tür (şahıslar) veya cins (türler) olmaktadır.

Cins ve türde anlam bakımından eşitlik, yani eşitanlamlılık (mutavatı) durumu söz konusudur. Bir tanımda mutavatı, bir anlam ile birçok şeye, yani fertlere delalet eden lafız olarak tanımlanmaktadır. Bu lafızda, anlamın varlığa delalet etmesi bakımından şeyler arasında herhangi bir fark yoktur, Aksine aralarında eşitlik vardır. Canlı lafzı gibi. Canlı lafzı, insan, at ve diğer canlılar için eşit anlamda kullanılır (Amidî 2016: 59). Cins kapsadığı türlere, tür kapsadığı bireylere eşitlikle isim olur ve onları bir araya getirir, toplar. İşte bu mutavatı durumudur. Altında türlerin sıralandığı cins, mutavatı durumuyla hem çokluk hem birlik olur. Yine bir tümel olarak tür, cins ve fasıldan meydana geldiği için bileşik (terkib) bir yapıya sahiptir. Bileşik olması ve şahısları içermesi bakımından ise tür de aynen cins gibi, bir çokluk ve birliktir (Kindî 2014c: 148). Şahıslar ise Kindî’ye göre maddîttikel şeylerdir. Bunlar fizik dünyasında var olurlar. Bu bakımdan şahıslar, Kindî’nin iki varlık dünyasından birisini oluşturur. Varlık dünyasının ikincisi olan cinsler ve türler ise şahıslar gibi değillerdir. Bunlar, duyular dünyasında var olmazlar, onların duyulur varlıkları da yoktur. Aksine ruhun tam güçlerinden birisinde var olurlar (Cihamî 2002: 16-17, 30).

Özsel (zâtî) cevherin ikincisinin ayırıcı cevher olduğunu söylemiştik. Ayırıcı Cevher (el-cevherî el-müferrik) lafzı, şeylerin tanımlarını birbirinden ayıran lafızdır. Yani ayırıcı cevher, şeyleri tanımda ayıran kavramdır. Sözgelimi bazı canlıları diğerlerinden ayıran "düşünen (nâtık)" lafzı, ikinci tür cevher olan "ayırıcı cevher"dir. Bu cevher, bazı nesneleri (eşya) birbirinden ayırır, o nedenle bu lafza "ayrım (fasıl)" adı verilir. Tür ve türün kapsamındaki 
şahısları ayırım (fasıl), yaptığı ayırımla onları cins içerisinde göstermesi bakımından da çokluk ve birlik ifade eder. Sonuç itibariyle her üç özsel tümelin (cins, tür, fasıl) ifade ettiği birlik, varlık için zorunlu değil, arızidir. Söz konusu arızilik yani arızî birlik sonradan olmaktadır. Sonradan olanlar ise bir başkasından ortaya çıkan "eser/sonuç" durumundadırlar.

\section{Özsel Olmayan (Gayrı Zâtî) Tümeller: Hâssa ve Araz-ı Âmm}

Yukarıda üç “özsel (zâtî)" tümeli ele aldık. Özsel (zatî) tümeller, Kindî metafiziğindeki tümellerin ilk grubudur. İkinci grubu, özsel (zâtî) olmayan, yani bağıl tümellerdir. Kindî bu tür bağıl tümeli, ikiye ayırır. Birincisi "özellik" yani "hâssa", diğeri "ilinti", yani "araz-1 âmm"dır. Bağıl olması bakımından Kindî bu iki tümele "araz" adını verir. Bağıl tümel yani arazın varlığı ve varlığını sürdürebilmesi, başkasına, yani cevherin varlığına, yok olması cevherin yok olmasına bağlıdır. Bu demektir ki bu tür tümel, cevherde bulunur. Cevher, onun zeminidir, konusudur. Bu bakımdan bağıl tümel, cevhere arı/ ilinti olandir.

Bağıl tümelin birincisi olan Hâssa, bir türü ve türün kapsadığ 1 şahısları ifade eder ve şeyin mahiyetini (inniyyet) bildirir. Hâssa mahiyetini bildirdiği şeyin cüzü değildir, bir çok şahısta bulunması bakımından çokluk ve birliktir. Cevherde bulunmasından, ya sadece bir türe/şeye özgü olmasından dolay1 hâssa denir veya bir çok türde/şeyde yaygın olarak bulunur ki bu tür araza da “ilinti (araz-1 âmm)" adı verilir. Kindî birincisine gülmek, ikincisine beyazlık kavramını örnek gösterir. Gülmek insan türünde bulunurken, yani insan türüne özgü iken, beyazlık bir çok şeyde, mesela; yaprakta, pamukta vb. birçok şeyde yaygın olarak bulunmaktadır. Bir çok şahısta bulunmasından dolayı da hem çokluk hem birlik ifade etmektedir.

Özet olarak her anlamlı lafız, beş tümeli yani ya cinsi, ya türü (suret), ya şahs1, ya ayrımı (fasl1), ya özellik'i (hâssayı) ya da ilintiyi (araz-1 âmm'1); beş tümel de hem çokluğu hem birliği ifade etmektedir. Birlik zorunlu olmayıp arazîdir, yani sonradandır. Beş kavramdaki tümellik, süreklilik (ittisal), birlik (ittifak veya ittihad), eşitlik, diğer adıyla eşanlamlılık (mutavatı), bileşiklik (terkib) durumlarıdır. Kindî’ye göre ittifak, herhangi bir durumda veya anlamda "iştirak" manası taşır (Kindî 2014c: 152). Çünkü varlığın (eşya) yapısı birlik ve çokluk karakterindedir. O nedenle tüm duyulur nesnelerde ve onlara ilişkin nesnelerde, birlik çokluğa iştirak etmiş durumdadır. Nerede çokluk varsa orada birlik vardır, nerede birlik varsa orada çokluk vardır. İşte bu durum, tümellerin varlık yapısıdır. 
Yine tikel varlıklar, Kindî’nin deyimiyle şahıslar, ya doğal (tabii), ya yapay (sınaî) nesneleri içerirler. Hayvan, bitki ve benzeri, doğal nesnelerdir (eşya). Ev ise yapay nesnedir. Birincileri doğal olarak, ikincisi yapay olarak süreklilik kazanmış nesnelerdir. Ev malzemenin bitiştirilmesi sonucu süreklilik kazanmıştır. Dolayısıyla tikeller, malzemeleri bakımından çokluk, bitişik yapısı bakımından birliği ifade ederler.

Sonuç olarak cins, tür ve ayrım cevher kategorisine; özellik (hâssa) ile ilinti (âraz-1 âmm) araz/ilinti kategorisine dâhil olur. Bunların yapısı ortaklık içerir. Bu ortaklık, birlik-çokluk ortaklığıdır. Söz konusu bu ortaklık, varlıkta ya birlik ve süreklilik (ittihad ve ittisal), ya eşanlamlllık (mutavatı), ya bileşiklik (terkib) durumu olarak ortaya çıkmaktadır. Yine özünde bitişik/sürekli (muttasıl) olan, niceliğin ayrımlarından (fasl) biridir, cüzleri arasında ortaklık bulunur, sonsuz bölünmeyi kabul eder. İkinci anlamda süreklilik, niceliğin bir arazı olarak ortaya çıkan sürekliliktir. Uçları aynı olan ve birbirine bitişik olan araz, sürekliliği/bitişmeyi ifade eder. Bir açının iki kenarının bitişmesi ve sürekliliği ortaya koyması böyledir (Uysal 2008: 202). Örnekler çoğaltılabilir.

Kindî varlığın yapısındaki söz konusu bu ortaklıktan ortaklığın sebebine ilerler ve varlıktaki ortak/müşterek yapıyı Bir'e delil yapar. Kindî’ye göre varlığın yapısındaki çoklukla birlik arasındaki ortaklık/iştirak, bir sebep sonucunda vuku bulmuştur. Çünkü çokluk birlerin toplanıp bir araya gelmesinden ibarettir. Bunun anlamı çoklukla beraber zorunlu olarak birlik bulunmaktadır. Yani iştirakin, bir sebebi vardır. Birliğin çokluğa iştirakinin sebebi, ya şeylerin kendisinden, ya başkasından gelmektedir. Bir şeyin kendisi, hem sebep hem sebepli olamaz; yani sebep sebepliden önce gelmek durumundadır. O nedenle tümellerdeki ortaklığın sebebi kendisi değildir. Yine birlik ve çokluğun birçok nesnelere iştirakinin sebebi, aynı cinsten olmaları, aralarında benzerlik bulunması da değildir. Şeylerin varoluşunun ve varlığını sürdürüşünün (sebat) gerçek sebebi, daha yüce (a'lâ), daha şerefli (eşref) ve şeylerin varlı̆̆ından daha öncesine giden bir sebeptir. Bu sebep, ilk sebeptir ki bu sebep Bir'dir ve Bir, illetli şeylerde mevcuttur.

Birlik ve çokluk ilişkisinden anlaşılacağı gibi Kindî, metafiziğini bir ve birlik kavramları üzerine kurmaktadır. Birliği yukarıda tümeller meselesinde ele aldık. Burada Biri ele alarak çalışmamızı tamamlayacağız.

\section{Bir (el-Vâhid) ve Birlik (Vahdet) Meselesi}

Kindî Biri ikiye ayırıp şöyle demektedir: "Şimdi kategorilerde hangi tür birlik vardır (الوحدة في المقولات), gerçek bir (الواحد بالحق) ve gerçek olmayan 
mecazî bir (الو احد بالمجاز لا بالحقيقة) nedir, söyleyelim. Onlardan önce bu konuda bilinmesi gerekenleri sunalım (Kindî 2014c: 161.”

Kindî’nin ifadesinde gerçek bir ve mecazî bir olmak üzere iki tür bir ile kategorilerde ortaya çıkan birlik yer almaktadır. Kategorilerdeki birlik mecazî birdir ve kategorilerde ortaya çıkan birliği bilmek için nitelik ve nicelik durumlarının bilinmesi gerekmektedir. Bunlar büyük-küçük (azîm-sağîr), azçok (kesîr-kalîl), uzun-kısa (tavîl-kasîr) iki kategoriyle ilgili durumlardır. Kindî’ye göre bunların, mutlak olarak bir şeye yüklenmediğini, ancak bir başkasına göre/nispetle yüklenildiğini belirtmemiz gerekir. Sözgelimi bir şey hakkında, ancak kendisinden "daha küçük" olana göre "büyük", büyük olana göre "küçük" denir. Olan bir felaket için, kendisinden daha büyük olana göre "küçük" denir. Kindî diğerlerini de örnekler. Sözü sayıya getirir. "Bir'in (el-vâhid) sayı, birlik'in (el-vahde)" azlık olma ihtimalini ele alır. Böyle bir iddianın, Bir için anlamsız olduğunu ve sonucunun da kötü-çirkin (şenâa kabîha) sonuçlanacağını belirtir. Çünkü eğer Bir, sayı olursa, sayı için nicelik söz konusu olacaktır. Yani niceliğe ait eşitlik, eşitsizlik, bölümlülük gibi nitelikler söz konusu olacaktır. O halde Bir, sayı değildir. Kindî niceliğin nitelikleri bakımından bir' in sayı olmasını reddetmiş olsa da sayılar maddeyi saymakta, onları nitelemektedirler. Sayıldığında ise bir maddeye sahip oldukları görülmektedir. Mesela "beş at" dediğimizde, "beş" ve "at" kavramları söz konusudur ve "at" beş sayısıyla sayılmıştır. Kavramlara dikkat edilirse madde, yani heyula beş için değil at için söz konusudur. O halde "beş" sayısı bir niceliği değil, onun aksine bir'i ifade etmektedir. Buradaki bir, beşi bir yapan başka bir değil, birliğin kavram olarak kendisidir. O nedenle birlik bir'dir, asla bölünmez. Ayrıca Kindî’ye göre bir'in ne ilkesi vardır, ne bir'i oluşturan bir sayı vardır. O nedenle bir, birleşik de değildir. Netice itibariyle Kindî”ye göre ilk sayı "iki”dir (Kindî 2014: 166-167).

\section{Gerçek Bir (el-Vâhid bi’l-hakîka)}

Gerçek Bir (el-vâhidü'l-hakk), nitelik ve nicelik kategorilerinin dışındadır. Cinsi yoktur, çokluk yoktur, bölünme, eksilme, çokluk yoktur. Çünkü çokluk, cins, tür, fasıl, şahıs, hâssa, araz-1 âmm, kül, cüz, cemi gibi kategorilere ilişkin olanlarda gerçekleşir. Gerçek Bir, bunlardan hiç biri değildir.

Gerçek Bir, hareket türlerine benzemez. Çünkü hareket, ya bir mekândan diğerine, ya artma (rubuv), ya eksilme (naks), ya oluş (kevn), ya bozuluş (fesâd) veya dönüşüm (istihâle) şeklinde olur. Hareket çokluk ifade eder.

Gerçek Bir nefis değildir, çünkü hareket nefiste vardır. 
"Duyu ve akılla algılanan her şey (kül), ya reelde (ayn) var olur (yekûne mevcûden), ya düşüncede (fikr) doğal olarak var olur (yekûne vücûden tabiiyyen), ya sözde (lafz) veya yazıda (hat) arazî olarak var olur (yekûne vücûden araziyyen). Hareket ise nefiste vardır (mevcûde) (Kindî 2014c: 169)"

Kindî hareketi, "düşüncenin (fikir) bazı şeylerin suretlerinden diğer bazı şeylere, nefsin çeşitli huylarından ve elemlerinden diğerlerine intikali" olarak açıklar ve nefsin öfke, korku, sevinç, üzüntü ve benzerlerine intikaliyle örnekler. İşte bunlar nefsin arazlarıdır. Dolayısıyla nefis, birlik ve çokluk halindedir. Gerçek Bir akıl da değildir. Kindî cins, tür, şahıs, bilfiil, bilkuvve kavramlarına döner. Bu küllî kavramlar nefiste ortaya çıktığında nefs akıl olur. Külliler çokluktur. O halde akıl da çokluk ifade etmektedir.

Gerçek Bir, müteradif (ortak anlamlı, anlamdaş) isim değildir. Müteradif, ortak anlamlı farklı kavramlar demektir. Sözgelimi bıçak anlamına gelen şefra, medye, sikkîn kavramları anlamda birdirler. Ama bu Bir, maddesi bakımından çokluktur. Gerçek Bir, benzer isim değildir. Mesela köpek kavramı iki ayrı anlama sahiptir. Birisi yırtıcı hayvan, diğeri yıldız'dır. Her ikisinin ismi köpek olması bakımından birdir. Yine yazı, söz, düşünce ve nesne cevher isminde birdir. Bunlarda isim benzerliği söz konusudur ve onlar isim benzerliğinde birdirler.

Gerçek Bir, maddî ilke de değildir. Maddî ilkesi aynı olanlar birdir. Mesela ahşaptan yapılan sedir, kapı gibi. Bunlar etki, edilgi, izafet veya diğer kategoriler bakımından farklıdırlar. Maddesi bakımından sedir ve kapı birdir, ama yine maddeleri açısından onlar bir çokluktur. Yine madde için bir oluş bozuluş söz konusudur. Sonuç olarak Gerçek Bir, her türlü kavramın üstündedir. Gerçek Bir, birlikle nitelenen varlıklardaki birliğin ilk sebebidir. O birliği başkasından almış değildir. Birlik ifade eden diğer bütün varlıklar sebeplidir. Gerçek Bir dışındaki her bir, gerçek değil mecâzî birdir. Mutlak Bir değillerdir. Mutlak Bir "asla çok olmayan ve zâtı (hüviyyeti) aynı olan”dır.

Metafiziğini çokluk-birlik kavramları üzerinde kuran Kindî, çokluğun sebebinin birlik olduğunu söyler. Ona göre çokluk birlik sayesinde varlık kazanmıştır (tehevvi). Eğer birlik olmasaydı, çokluğun varlığından söz edilemezdi. Her varoluş (tehevvin), olmayanı varlayan (yûcedu) bir etkilenme (infiâl) durumudur. Kindîye göre bu etkilenme, Gerçek Bir'den gelen birlik feyzidir (feyzü'l-vahde). Bu birlik feyzi, her duyulura ve duyulurlara eklenen niteliklere varlık verir (tehevvi). Şu halde varoluşun sebebi, Gerçek Bir'dir. O birliği başkasından almamıştır. Bizâtihi Bir'dir. Varoluşun sebebi, ilk gerçek Bir olduğuna göre yaratmanın (el-ibdâ) sebebi de ilk Gerçek Bir'dir. O nedenle Gerçek Bir, ilk olan, yaratan, varlığa süreklilik verendir. 


\section{SONUÇ}

Kindî metafiziği, İslam metafiziğinin başlangıç metafiziğidir. Kindi felsefesinde meta-varlık, iki temel problemi içermektedir. Birincisi varlığın İslam düşüncesindeki izdüşümlerini, diğer bir ifadeyle varllğın müştereklerini; ikincisi varlığın gerçekleşme biçimlerini (hakaik), genel bir ifadeyle hak ile bağını kuran özsel niteliklerini içermektedir.

Varlığın izdüşümleri (müşterekleri) olarak meta-varlık, Kindî metafiziğinde şey ve çoğulu eşyâ, eys ve çoğulu eysât, inniyye ve çoğulu inniyyât, vücûd, mevcûd, hakk ve bir kavramları olarak görünmektedir. Kindî’ye göre eşyâ'nın hakikatini (hakâik) aramak ve bilmek, ilaveten eylemek felsefe olmaktadır. Hakaik bilgisi içerisinde ise kökü peygamberlere kadar giden Rubûbiyyet ilmi, Vahdâniyet ilmi, Fazîlet ilmi ve Yararlının İlmi olmak üzere dört tür bilgi bulunmaktadır.

Hak kavramı hakikatin kökü ve illeti olması bakımından gayedir. Gerçeklik için kullanılan diğer varlık kavramları, "vücûd, eysât ve inniyyât" kavramlarıdır. Sözgelimi inniyye şeyin zihin haricindeki mahiyeti için, eys yokluğun zıddı olan varlık için kullanılan kavramdır. Bu iki kavramı Kindi, birlikçokluk meselesini ele alırken, birliğin varlığını ispatlarken kullanmaktadır. Kindi tümelleri de birlik-çokluk bağlamında ele alır. Tümeller müşterek kavramlardır. Onları özsel (zâtî) olup olmamaları bakımından ikiye ayırır. Çünkü özsel olan şey'i var kılan ilkesidir. Bu ilke, vücûd'dur. Kindi şeyin varolmasını özsel ilkesiyle olduğunu ifade etmek üzere mukavvim, bir diğer türeviyle kıvam kavramlarını kullanarak anlatır. Yani vücûd, şey’in varolmasını ve sabit olmasını sağlayan ilke olur. Bu aynı zamanda şey'in hakikatidir. Hay (canlı, diri) ve hayat (canlılık, dirilik) örneği gibi. Diri, dirilik ile varolur. Aksi durumda diri, varlık alanından çekilir.

İnsan söz konusu olduğunda Kindî vücûd'u duyusal ve aklî varlığı ifade ederken kullanmakta, duyusal varlık, duyuların algıları olup zihinde ortaya çıkmakta, hafizada depolanmakta, "mesel, mütemessil" adını almaktadır. Aklî varlık, duyusal varlıktan elde edilmekte, "aksiyomlar (evâil)" adını almaktadır. Kindî mevcudu ise, "vardır” karşılığında bir yüklem/fiil olarak kullanmaktadır. O nedenle mevcûd, bir dilsel varlıktır.

Meta-varlığın ikinci temel problemi, müşterek varlıklar diye ifade ettiğimiz varlık izdüşümlerinin gerçekleşme biçimleridir ki bunlar Kindî felsefesini ve felsefesinin mahiyetini ortaya koymaktadır. Varlığın izdüşümleri öncelikle birer lafızdır ve lafız, varlık anlamı içermektedir. Bu anlam ya harice yani 
ayn'a, ya zihne yani düşünceye (fikr), ya ağızdan çıkan sözde (lafz) ya da yazıda (hat) var olmaktadır. Bu bakımından lafızlar müşterekliği ifade etmektedirler. Kindî, müşterek varlık lafzından reel varlığa ve onun gerçekleşmesine hak ve hakikat kavramlarıyla geçiş yapmaktadır. Onlar şeylere aittirler ve birdirler. Müşterek varlıktan reel varlığa/şeye geçişi sağlayan ikinci kavram, ebedî ve küllî adını verdiği kavramlardır (eşyâ). Bunlar birdir-çoktur, birliktir-çokluktur ve bunlar varlığ gerçekleşen nitelik ve nicelik kategorileridir. Neticede müşterek varlık meselesinde metafiziğin konusunu, Kindî’ye göre tümeller sorunu oluşturmaktadır. Kindî’nin Aristocu bir anlayışla beş tümeli, cins, tür ve ayrım üç özsel (zâtî) tümel, hâssa ve araz-1 âmm iki arazsal tümel ile onların varolma biçimleri olan, birlik ve çokluk, yani zıtların birlikte varoluş durumudur.

Kindî metafiziğinde bir diğer problem sayılar ve Bir problemidir. Fisagorcu ve Platoncu bir anlayışla Kindî, sayıların ikiden başladığını, sayıların hem çokluğu hem birliği içerdiğini belirtir. Bir'i ise sayı kabul etmez, onu Bir (varlık) kabul eder. Bir'i ikiye ayırır. Gerçek Bir, Mecazî Bir. Mecazi Bir, şahıslarla gerçekleşen bir ve birliktir. Onları gerçekleştiren ise ilk sebep olan Bir'dir. Bu tür bir, gerçektir, mutlaktır, çok ve çokluk değildir. Bölünme ve değişim söz konusu değildir. Böylece meta-varlığın ikinci problemini Kindî, "zitlar ve sebebi" temelinde iki Bir'den ve bir Birlik'ten (vâhid ve vahdet) oluşan bir 'Bir metafiziği' olarak ortaya koyar. 


\section{KAYNAKLAR}

Cihamî, Cirar (2002). Mevsuatü mustalahâti'l-Kindî ve'l-Farabî, Lübnan: Mektebetü Lübnan.

El-Âmidî, Seyfüddin Ali b.Muhammed (2016). El-Mübin fi şerhi meân̂̂ elfâzi'l-hukemai ve'l-mütekellimin, çev.B.Taşkın-O.N.Demir, İstanbul: İz Yayıncilık.

Erdem, Engin ve Necmettin Pehlivan, (2012). "Varlığın ve Yokluğun Ötesi: Kemalpaşazâde'nin “Leys ve Eys'in Anlamının İncelenmesine Dair Risâle"si”, İslâm Araştırmaları Dergisi, 27, s.87-116.

İbn Hazm (2015). er-Red ale'l-Kindî el-feylesuf, çev.M.Uyanık-A.Akyol-S. Bolat, Ankara: Elis Yayınları.

İbn Manzur, Lisanu'1-Arab, Daru'1-mearif, Trhsz. Kahire, c.5.

Kindî (2014a). Fi'l-Hudûd ve'r-rusum, Felsefi Risaleler, çev.Mahmut Kaya, İstanbul: Klasik.

Kindî (2014b). Kitabu'l-Cevhâiri'l-Hamse, Felsefí Risaleler, çev.Mahmut Kaya, İstanbul: Klasik.

Kindî (2014c), Fi'l-felsefeti'l-ûlâ, Felsefí Risaleler, çev.Mahmut Kaya, İstanbul: Klasik.

Kindî (2014d). “el-Fâilü'l-hakku'l-evvelü't-tâmm ve'l-fâilü’n-nâk1s ellezî hüve bi'l-mecâz”, Felsefi Risaleler, çev.Mahmut Kaya, İstanbul: Klasik.

Kutluer, İlhan (2010). "Şey”, Diyanet İslam Ansiklopedisi, c.39, s.34-36, İstanbul: Diyanet Vakfi.

Öçal, Şamil (2000), Kemalpaşazâde'nin Felsefi ve Kelâmî Görüşleri, Ankara: Kültür Bakanlığı.

Türker, Ömer (2018). "Kindî Metafiziği”, Diyanet İlmî Dergi, c.54, say1 2, s.53-66.

Uysal, Enver (2008). Kindî ve İbn Sina Felsefesinin Temel Kavramlarl, Bursa: Emin Yayınları.

Yavuz, Yusuf Şevki (1995), "Eys", Türkiye Diyanet Vakfi İslâm Ansiklopedisi (DIA), c.XII, İstanbul: Diyanet Vakfi. 
